\title{
THE CONSTRUCTION OF MURTADHA MUTAHHARI'S THOUGHT REGARDING DIVINE WILL AND HUMAN'S WILLING
}

\author{
Fathurrahman \\ Institut Agama Islam Muhammadiyah (IAIM) Sinjai \\ J1. Sultan Hasanudin No.20, Balangnipa, Sinjai Utara, \\ Kabupaten Sinjai, Sulawesi Selatan 92614 \\ Email: filosopiah@gmail.com
}

\begin{abstract}
This article discusses the thoughts of Mutahhari Mutahhari about Divine Will and Human Will, Research Objectives, To know and understand how the construction of the Divine will and human will in the view of Mutahhari Murtadha. This type of research is a descriptive qualitative research. The approach used is a philosophical approach, but the philosophical approach used in this thesis is the Islamic philosophical approach (disposition). The data source is divided into two, namely primary data sourced from Motahhari's works and secondary data which are related to Motahhari's thoughts. Data processing and analysis techniques are done by using the process of arranging data sequences, organizing them in a pattern, category and basic description units, and the data analysis used in this study is qualitative analysis, this method is intended that the analysis departs from the data and leads to conclusions General research results show that there is a link between the Divine will and the human will, where both (Divine will and Human will) are not in conflict. The Divine Will in this case the Divine destiny does not confine man and destroys it even it is Divine destiny that makes man free and independent in choosing what he wants.
\end{abstract}


Keywords: The principle of causality, definitive destiny, nondefinitive destiny, Divine will and human will.

\section{Introduction}

Islamic thought is an important part of the many intellectual legacies left by classical Islamic thinkers, and has become the spirit of all aspects, both political, social, economic and theological. In the history of the development of the following theology, a number of theological thoughts were born which colored Islam in the field religious scholarship. History tells us that theological discussion began in the middle of the first century Hijri, and the problem of "predestination and freedom" is the most classic theological problem. ${ }^{1}$

Mutahhari is known as a famous Muslim scholar and intellectual. He studied all the religious knowledge (Islam) that existed in his time, with an emphasis on philosophical and mystical aspects. In this case, in addition to loving the Islamic religious sciences, he was also very interested in Divine philosophy. The background of the emergence of Mutahhari's thoughts about the Divine will and human will is due to the accusation stating that the Divine will manifested in destiny or qadha and qadar is a factor in the decline of Islam. ${ }^{2}$

${ }^{1}$ Murtadha Muthahhari, Al-'Adl al-Ilahiy terj. Agus Efendi, Keadilan Ilahi (Jakarta: Mizan, 2009), p. 15.

${ }^{2}$ Murtadha (Muthahhari, al-Insan wa al-Mashir, Terj. Manikmaya, Manusia dan Takdirnya, 2001) Muthahhari, al-Insan wa al-Mashir, Translation. Manikmaya, Manusia dan Takdirnya, (Bandung: Muthahhari paperbacks , 2001), p. 14 
The problems of the Divine will and human will (destiny) or the determination of fate, are among the most complicated philosophical issues and the philosophy of God, but they are among the most important socio-political problems caused by two things, first the intuitive reaction related to the form individual thought of each discussion of this problem on practical life, and how to handle all events that occur. Naturally, if there is a difference in mentality and behavior between someone who believes that he is a shackled form, with others who believe that he himself is in complete control of his future and destiny. ${ }^{3}$

From the middle of the first century onward, when two thoughts on this question emerged, a group of people supported the flow of human freedom and its ideas and shook off a collection of verses about determinism. They are known as the Qadariyah. ${ }^{4}$

While other groups support the flow of supernatural supernatural powers that dominate all human activities, they suppress a set of verses that proclaim human freedom. They are known as the Jabariyah. ${ }^{5}$

With regard to the understanding of the Murtadha and the views of various theological streams on Divine justice related to the will of Allah swt and human will, in this study

${ }^{3}$ Murtadha Muthahhari, al-Insan wa al-Mashir terj. Manikmaya, Manusia dan Takdirnya, p. 3.

${ }^{4}$ Abd al-Jabbar, Syarh Usul al-Khamsah, ( al-Qahirah: Maktabah Wahbah, 1965), p.323.

5al-Ghurabi, Tarikh al-Firaq al-Islamiyyah wa Nashb'at 'ilm al-Kalam, (al-Qahirah: Maktabat Muhammad 'Ali Sabhi, cet. 2, 1958), p. 2930. 
the author attempts to study and examine the relationship or construction of God's will and human will in Murtadha's view. For this reason, in this journal the author considers urgency to be studied in depth by the analysis of the construction of Divine will and human will in the view of Murtadha Muthahhari. From the above descriptions the researcher seeks to understand and understand how the construction of Divine will and human will is shaped in the view of Murtadha Muthahhari, whereas the benefits of writing this journal are to provide information on the richness of Isalm's thinking on the issue of divine will and human will.

\section{Literature Review}

Studies on thoughts related to Divine justice and destiny have been carried out by researchers, both in the form of books, articles or in other scientific writing forms, both those related to thoughts of the Divine will and human will according to Murtadha Mutahhari, as well as those not related to thought Murtadha Mutahhari. Next I will explain the study of the Divine will or Divine destiny, with the human will associated with the thoughts of Murtadha Mutahhari or unrelated.

Journal entitled "Apostasy Thought of Mutahhari on Divine Justice" The Scientific Journal of Islam, Vol.5, No.2, December 2006, written by Mawardi Ahmad. In the journal gives an explanation of Motahhari's thoughts about Divine justice is a combination of rational and spiritual patterns. This can be seen in the use of the method of thinking and the 
method of analysis approach. The method of thinking it uses is a combination of spiritual insight with philosophical deduction methods.

In the journal above the author focuses on Divine justice in the form of the form of a form that may obtain form if it has met its conditions of perfection. So the substance of the rich and the merciful God must bestow his grace with the potential fulfillment of his potential. So the authors of the above journal show justice in Murtadha Muthahhari's view, that divine justice is related to the activation of the potential for realization when conditions are met. Whereas the research in this Journal aims to establish the relationship between Divine Will and Human Will in other words Divine will manifest in human free will.

Then the journal entitled "Takdir dan Kebebasan Manusia Menurut Fethullah Gulen" in the journal Islamic and Social Studies Forum. vol 25, no 2, July-December 2014. The journal written by Anang Haderi explained Fethullah Gulen's view that human destiny and freedom seemed to want to combine the provisions of the Koran (revelation) and the potential of reason possessed by humans. However, at the same time he also reminded humans to always be consistent in the path of destiny in terms of the goodness that God has outlined. Humans in his view do have free will, but that will must be in accordance with God's will.

From the description above, it is clearly seen that Fethullah Gülen understands the destiny and free will that had become a debate among Muslim theologians did not fully 
favor any sect. He tried to offer his own theological thinking by using language that is touching human conscience awareness. This is what distinguishes the above journal from this thesis, where this research intends to show the relationship between the divine will and human free will, in other words the Divine will does not conflict with human freedom. The similarity of the above article that wants to explain the relationship between destiny with human free will.

In the journal Theology and Pastoral Studies, the journal entitled "Providensia Allah dan Kehendak Bebas Manusia" vol 2, no 2, July 2004, journal written by Jaffray. the author tries to relate God's providence to man's free will and states that providence is God's maintenance of all his creation which takes place in eternity (God's total plan), God provides for his creation according to his will, in order to direct it to the planned goal.

Free will is the ability of humans to act under God's control because they are responsible for God's commands, in order to achieve the purpose of God that He has established in eternity. Human free will in this matter acts freely to do God's command, not to do human's free will.

In this paper as far as researchers study, humans are not given freedom because at any time God takes direct action on humans through miracles and this according to the researchers removes human free will, and this is the direction that the researchers' surgical point with the author above about the relationship of God's will. with human freedom. 


\section{Research Methodology}

1. Type of Research

This type of research is descriptive qualitative. Qualitative because it uses data in the form of verbal statements and library data related to the views of the Divine will and human will according to Murtadha Mutahhari, not numbers. Qualitative research is the process of finding data to understand the problem as a whole (holistically) formed by words and obtained from natural situations. One of them is descriptive. Descriptive is a study that aims to describe a fact systematically, factual, scientific, analysis, and accurate. ${ }^{6}$

\section{Research approach}

The approach that the author uses in this thesis is a philosophical approach. But in this study the authors used an Islamic philosophical approach (disposition). Disposition is the division of mental concepts into two types, namely primary concepts and secondary concepts, primary concepts are the conceptual foundation of human thought. This primary concept results from direct sensory perception of the charge. Whereas the secondary concept is the concept of rationality born from primary concepts. So the secondary concept is a derivative of the primary concept, relying on the reason that what the writer studies is thought, especially in terms of knowing the true thoughts of Mutahhari Murtadha.

${ }^{6}$ See Cholid Narbuko dan Abu Achmadi, Metodologi Penelitian (cet. III; Jakarta: bumi aksara, 2001), p.44. 
This approach is not included in sociological, cultural or political areas. ${ }^{7}$

\section{Data Collection Methods}

This research is entirely in the form of library research (library research), which uses library sources in discussing the main problems and sub-problems that have been formulated. Data collected through library research consists of primary and secondary data. ${ }^{8}$ The primary data are derived from the works of the Murtadha Mutahahhari such as his works Al'Adl al-Ilahiy (Divine justice) and al-Insan wa al-Mashir (human and his destiny) while the secondary are all works related to the Murtadha Mutahahhari thought such as the book of the World itself and the book Why we were created.

Because this study is a thought-provoking study it is possible to use references that are also used by the person being researched, in particular the theories about and involving the discussion of divine will, human will and divine justice.

\section{Data Processing and Analysis Techniques}

Data analysis is one of a series of very important and decisive research activities. According to Patton, data analysis

${ }^{7}$ Anton Baker \& A. Charris Zubai, Metode Penelitian Filsafat (Yogyakarta: Kanisius, 2000), p. 6.

${ }^{8}$ See Jujun S. Suriasumantri, Penelitian Ilmiah, Kefilsafatan, dan Keagamaan: Mencari Paradigma Kebersamaan, Mastuhu dan deden ridwan (ed.), Klasifikasi Ilmu dan Paradigma baru Penelitian Keagamaan: Tradisi baru Penelitian Agama Islam (Jakarta: Pusjarlit-IAIN \& Penerbit Nuansa, 1998), h.44. 
is a process of arranging data sequences, organizing them into patterns, categories and basic units of description. ${ }^{9}$

a. The data analysis method used in this study is qualitative analysis. This method is intended that the analysis departs from the data and leads to general conclusions. The data analysis technique uses content analysis techniques, namely, research conducted on information documented by recording, both in pictures, sounds, and writing. The steps of data analysis are as follows:

b. Select and determine the subject to be studied

c. Collecting data in accordance with the subject matter through books and other sources.

d. Analyze and clarify. ${ }^{10}$

\section{Results and Discussion}

The question of divine will and human will does not depart from the question of qadha and qadar. Qadha is the setting of the law, or the termination and judgment of something. A qadhi (judge), so-called because he is on duty or acts as judge and adjudicates between two persons who have disputes in court. Qadar means a certain level and size. The events of nature, reviewed from the point of existence

\footnotetext{
${ }^{9}$ Kaelan, Metode Penelitian Kualitatif Interdispliner (Yogyakarta:Pradigma, 2012), p. 130.

${ }^{10}$ Suharismi Arikunto, Prosedur Penelitain Suatu Pendekatan Praktek (Jakarta: PT. Rineka Cipta, 1988), p. 309.
} 
under the supervision and will of God, can be grouped into the Divine qadha, and from the limits of their nature to a certain size and rate and their position in space and time, can be grouped into the divine qadha .

The issue of Divine Will is closely related to the problem of the knowledge of Allah, the Creator, and the levels of knowledge. In turn, this is also related to many other issues, among other things, about the (scientific) study of the universe. So all these natural phenomena are included in only three possibilities. ${ }^{11}$ First, that natural events are not related to the past that preceded them, either ahead of time or other, and therefore their existence is not related to everything that preceded them. Similarly, all the characteristics or characteristics.

Whereas the principle of cause and effect or general causality and the dharuri and definite connection between all events, and that each event obtains the capacity and necessity and the specificity of its existence from one or many other things that preceded it, are things which are accepted without doubt and do not require refutation. ${ }^{12}$ If this is compared with al-Baqillani's opinion ${ }^{13}$ which states that the karan is new, then it is made up of jawhar, arad and mass, then there is influence given by cause to effect.

${ }^{11}$ Murtadha Muthahhari, al-Insan wa al-Mashir transl. Manikmaya, Manusia dan Takdirnya, p. 20.

${ }^{12}$ Muhammad Baqir Shadr, falsafatuna, transl .Arif Maulawi, filsafat kita, p. 271.

${ }^{13}$ al-Baqillani, al-Tahmil al-Awa'il wa Talkhis al-Dala'il, (Bayrut: alMaktabah al-Sharqiyyah, 1957), p. 41. 
The latter acknowledged that each incident had a single precedent, but denied the existence of a causal system that occurred between all events. Thus, everything comes directly from the first and foremost reason, namely Allah.

The three statements that the concept and system of causation are common to nature and all events and events therein. Each event captures the essence of its existence, its shape, its characteristics in relation to space and time and its distinctiveness other than the causes that precede it. ${ }^{14}$ Here Mutahhari explains that the consequence of accepting a causal theory or a system of general causation is to accept that every event acquires the capacity of being, characteristics, form, content and quality from its cause, and this al-Jawani explains the first cause or creator is God. ${ }^{15}$

In terms of human liberty and belief, Muthahhari explains between qadha and qadar or divine provisions and resolutions in the system of causal linkages between divine will and human will is not identical with Jabariyah. This would have happened if we had not given any role to man in creating his own behavior, by giving unanimously to destiny, as understood by the Jabariyah who declared that Allah's power is infinite, that God is the creator of all things, including man and his works. ${ }^{16}$ kita, p. 275.

${ }^{14}$ Muhammad Baqir Shadr, falsafatuna, Terj.Arif Maulawi, filsafat

${ }^{15} \mathrm{Al}-J a w a i n i$, al-Irsyad ila Qawati' al-adillah, (Misr: Matba at alMaktabah al-Khariji, 1959), p. 30.

${ }^{16}$ Ali Mustafa al-Ghurabi, Tarikh al-Firqa al-Islamiyyah, p. 24-25. 
It is unacceptable to say that God does anything without an intermediary. Even the truth is that God has required the creation of all things through special causes and causes. Even rejecting the role of the previous causes will be the same as accepting the concept of coincidence, even in the framework of human will it will be a mere coincidence. However, the principle of causality that bridges the Divine will and the human will is impossible to ignore or exclude, and in the event of all disconnection between human acts and the reasons behind it, human nature will have no meaning or freedom in making choices. ${ }^{17}$

In Mutahhari's view which is quoted from various religious histories and al-quran cues, Mutahhari understands that there are definitive destinies and non-definitive destinies, this shows that there are two types of qadha and qadar, namely those that have changed and have not changed, things the same is explained by Thabathaba' ${ }^{18}$

In this regard Muthahhari explains the Divine will manifested in destiny, saying that the emergence of all causes and causes of God's will and knowledge, which is why all causes are definitive. Where everything is fixed and confirmed. As for the change of fate in the sense that the cause of change itself is the activity of qadha and qadar and one of a series of causes or, in other words, the change of

${ }^{17}$ Murtadha Muthahhari, al-Insan wa al-Mashir transla. Manikmaya, Manusia dan Takedirnya, p. 25.

18'Allamah Thabathaba'I, Nihayat al-Hikma, (Qum alMusyarrafah: Mu'assasat al-Nasyr al-Islami, 1404) p. 309. 


\section{Fathurrabman}

destiny by destiny and the replacement of destiny with the determination of one's own destiny in accordance with divine knowledge and will, then it is it is a fact, though it looks strange and muscular. ${ }^{19}$ In other words, the secret of the question of the possibility of a change in fate is contained in the fact that qadha and qadar require the existence of each realization through their own reasons, and the existence of it without it. On the other hand, the causes and effects of nature vary, while these natural things can be influenced by a variety of causes at the same time. ${ }^{20}$

Human actions and actions are among the events above which there is no definitive qadha and qadar, because humans are linked to thousands of causes and causes, including all kinds of desires and choices that humans have and have. All the ability to accumulate in large quantities on the things, plants and actions of animal instincts, is in the works of man. In the growth of any tree, or in any act of animal instinct, there are thousands of natural conditions that make it possible. All of these conditions are also present in human actions and actions, especially because humans are given the intellect, feelings, moral will, and the power to choose. $^{21}$

${ }^{19}$ Contrast with the jabariyah understanding that man is not released from the grasp of destiny. Harun Nasution, teologi Islam, p. 121. Islam, p. 82.

${ }^{20}$ Muhammad Husaini Bahesyti dan Jawad Bahonar, Philosophy of

${ }^{21}$ Murtadha Muthahhari, al-Insan wa al-Mashir transl. Manikmaya, Manusia dan Takdirnya, p. 37. 
In this case the researcher understands that Mutahhari's view of understanding human actions is not in deterministic qadha and qadar, because of the many reasons or causes that are the beginning of human actions. What is in plants, and what is in animal instincts also exist in humans, and the principles of natural existence which are essentially manifested from various causes or reasons are also found in humans. Moreover, humans with human factors, in this case, namely knowledge, ${ }^{22}$ and his will to choose also plays a role in every aspect of his life. So that humans are not trapped in deterministic qadha and qadar.

\section{Conclusion}

Based on the results of the study stated previously, can be concluded as follows:

That the divine destiny outlined through qadha and qadar is not identical with jabr, this is due to the existence of many series of causes which can influence human actions or choices together, on the other hand humans are awarded with various reasons because it makes them free to do his deeds, and the most influential is human knowledge. The existence of various factors or causes that influence something that simultaneously causes the division of destiny. Namely, the definitive destiny and the fate that is not definitive, and humans are in a destiny that is not definitive this is due to the many series of cause and effect that can affect human actions

22al-Markaz ar Risalah, al-Amru Baina al-Amrain, terj. Muhsin Assegaf, Keadilan Tuhan, Determinisme Sejarab dan Kemandirian Tindakan Manusia, (Jogyakarta: RausyanFikr Instute, 2012), p. 5. 
and actions.

\section{REFERENCES}

al-Baqillani. (1957). al-Tahmil al-Awa'il wa Talkhis al-Dala'il. Bayrut: al-Maktabah al-Sharqiyyah.

al-Ghurab. (1958). Tarikh al-Firaq al-Islamiyyah wa Nashb'at 'ilm alKalam, cet. 2. al-Qahirah: Maktabat Muhammad 'Ali Sabhi. al-Ghurabi. (1958). Tarikh al-Firaq al-Islamiyyah wa Nashb'at 'ilm alKalam. al-Qahirah: Maktabat Muhammad 'Ali Sabhi.

al-Jabbar, A. (1965). Syarh Usul al-Khamsah. al-Qahirah: Maktabah Wahbah.

Al-Jawaini. (1959). al-Irsyad ila Qawati' al-adillah. Misr: Matba at alMaktabah al-Khariji.

Arikunto, S. (1988). Prosedur Penelitain Suatu Pendekatan Praktek. Jakarta: PT. Rineka Cipta.

Bahonar, M. H. (t.th.). Philosophy of Islam. Iran: Ansariyan Publication.

Cholid Narbuko, A. A. (2001). Metodologi Penelitian. Jakarta: Bumi Aksara.

Kaelan. (2012). Metode Penelitian Kualitatif Interdispliner. Yogyakarta: Pradigma.

Marnan, e. a. (2006). Metodologo Penelitian Agama: Teori dan Praktek. Jakarta: Raja Grafindo Persada.

Moleong, L. J. (2002). Metodologi Penelitian Kualitatif. Jakarta: Remaja, Rosdakarya.

Muthahhari, M. (2009). Al-'Adl al-Ilabiy terj. Agus Efendi, Keadilan Ilabi. Jakarta: Mizan. 
Muthahhari, M. (2001). al-Insan wa al-Mashir, Terj. Manikmaya, Manusia dan Takdirnya. Bandung: Muthahhari paperbacks.

Ridwan, M. d. (1998). Klasifikasi Ilmu dan Paradigma baru Penelitian Keagamaan: Tradisi baru Penelitian Agama Islam. Jakarta: Pusjarlit-IAIN \& Penerbit Nuansa.

Risalah, a.-M. a. (2012). al-Amru Baina al-Amrain, terj. Mubsin Assegaf, Keadilan Tuhan, Determinisme Sejarah dan Kemandirian Tindakan Manusia. Jogyakarta: RausyanFikr Instute.

Shadr, M. B. (2018). Falsafatuna, Terj.Arif Maulawi. Yogyakarta: RausyanFikr Institute.

Suriasumantri, J. S. (1996). Filsafat Ilmu: Sebuah Pengantar. Jakarta: Pustaka Sinar Harapan.

Thabathaba'I, A. (1404). Nibayat al-Hikma. Qum al-Musyarrafah: Mu'assasat al-Nasyr al-Islami.

Zubai, A. B. (2000). Metode Penelitian Filsafat. Yogyakarta: Kanisius. 